\title{
Analýza výstupů dramatické výchovy a klíčových kompetencí
}

\section{The analysis of outputs in drama education and key competencies}

\author{
Jan Karaffa
}

\begin{abstract}
Abstrakt: V př́ispěvku hledáme odpovědí na otázku: Jaký potenciál má dramatická výchova k rozvíjení klíčových kompetencí? Východiskem byly odborné publikace, články a oficiální dokumenty z českých, ale i zahraničních zdrojů, vnichž se objevují souvislosti mezi dramatickou výchovou a klíčovými kompetencemi s tendencí k zachycení určité kvality procesu a výstupů učení. Hlavní metodou se stala analýza dokumentů, na jejímž základě vznikal systém kategorií, pro které byly postupně vyhledávány výskyty činitelů vyjadřujících kvalitu dílčích oblasti dramatické výchovy. Následně šlo o jejich třídění na základě vymezených kategorií, které mohou tvořit také strukturu jednotlivých klíčových kompetencí. Jedním z výsledků je tak popis konkrétních výstupů dramatické výchovy, jejichž naplňování může mít vliv na rozvoj klíčových kompetencí a rozpracování kritérií k zaznamenávání jejich kvality, což se ukazuje také jako vhodné východisko pro kvalitativní i kvantitativní výzkum a deskripci stavu klíčových kompetencí v jejich různých etapách vývoje v reálné školní praxi.
\end{abstract}

Klíčová slova: dramatická výchova, klíčové kompetence, kvalitativní výzkum, konstantní komparace

\begin{abstract}
In this paper, we are looking for answer to the questions: What potential does the drama education have on the development of key competencies? The professional publications, articles and official documents from Czech and foreign funds, in which drama relationship between education and key competencies is covered, have become a starting point, as well as a tendency to capture some quality of process and outcomes of learning. The main method was the analysis of documents, under which the system of categories gradually searching for occurrences of sub-factors representing the quality of the drama education, has been created. Consequently, their classification on the basis of defined categories, which can also form the structure of key competencies, has been done. One result is the description of the specific outcomes of drama education, whose implementation may influence the development of key competencies and setting of criteria for their quality recording, which looks like a suitable method for qualitative and quantitative research and description of the status of key competencies in their various stages of development in a real school practice.
\end{abstract}

Keywords: drama education, key competencies, qualitative research, analysis of documents

\section{1 Úvod}

Dramatická výchova má rozvíjet osobnostní, sociální i umělecké schopnosti a dovednosti žáků. Lze tedy předpokládat, že součástí takového procesu učení mohou být i klíčové kompetence. Zatím nezodpovězenou otázkou však zůstává, nakolik odpovídá tento předpoklad reálné skutečnosti. Proto považuji za důležité se problémem podrobněji zabývat a nalézat konkrétnější odpovědi pro taková tvrzení. 


\section{Teoretická východiska}

Dramatická výchova (drama) umožňuje poznávání života lidí a dramatického umění prostředky dramatu a divadla na základě zkušeností a prožitku. Drama se objevuje v různých státech $\mathrm{v}$ Evropě v rozmanitých podobách: samostatný předmět, součást jiného předmětu nebo oblasti a jako volitelný předmět. ${ }^{1}$ Je tedy zcela zřejmé, že jenom v jedné čtvrtině evropských zemí je drama ve vzdělávacím systému nabízeno pouze jako volitelný předmět a k těmto zemím se řadí i Česká republika. Kličové kompetence (KK) jsou stále základním vzdělávacím cílem rámcových vzdělávacích programů, přestože je v poslední době pozornost zaměřena především na výsledky, které jsou součástí testování a následně i porovnávání školních výkonů žáků.

V odborné literatuře se objevuje v poměrně širokém spektru popis možností, které nabízí dramatická výchova pro rozvíjení osobnosti v mnoha rozmanitých oblastech (Baldwin, 2008 aj.). Většinou jde však o zaměření na rozvoj schopností a dovedností v obecnější rovině a to především ve vztahu k obsahu procesu učení dramatické výchovy. U některých autorů se objevuje i přesah přímo ke klíčovým kompetencím. Patrná je i snaha po zaznamenávání konkrétních výsledků $v$ rámci dlouhodobějšího procesu a ověřování vlivu uměleckých aktivit (Turner et al. 2004), kde autoři v rámci evaluace sestavili několik na sebe navazujících kroků, aby zaznamenávali u účastníků změny $\mathrm{v}$ rámci programu dramatických aktivit Národního divadla v Londýně s propojením na kurikulum v primárním vzdělávání a požadované výsledky vzdělávání v letech 2002-2004.

$\mathrm{Na}$ základě rešerší, třídění a analýzy 261 odborných publikací (článků v odborných periodikách a oficiálních dokumentech u nás i ze zahraničí) došel tým ${ }^{2} \mathrm{k}$ závěru, že jde o téma, kde prozatím u nás ani v zahraničí nejsou konkrétní výsledky prrímo ve vztahu dramatické výchovy ke klíčovým kompetencím, ale existují studie i výzkumy, které se mohou stát inspirací, např́íklad Turner et al. (2004) viz výše.

\section{Cíl a otázky}

Hlavním cílem je popsat souvislosti mezi výstupy dramatické výchovy a klíčovými kompetencemi žáků a odpovědět na otázky:

- Jaký potenciál nabízí dramatická výchova k rozvíjení klíčových kompetencí?

- Jaké jsou souvislosti mezi očekávanými výstupy a klíčovými kompetencemi?

- Co konkrétně musí žáci zvládnout, aby došli k očekávaným výstupům?

- Může naplňování výstupů dramatické výchovy napomáhat rozvíjení některých složek klíčových kompetencí?

- Které rozpracované výstupy mají něco společného s dílčími úrovněmi klíčových kompetencí?

\footnotetext{
${ }^{1}$ Dle studie Delhaxhe, A., Baïdak, N., Horvath, A. et al. (2009) poskytující informace o uměleckém a kulturním vzdělávaní v povinném všeobecném vzdělávaní.

2 Šlo o realizační tým, který vznikl v rámci ročního projektu SGS Ostravské univerzity v Ostravě Nástroje evaluace klíčových kompetencí žáků 1. stupné základníškoly ve vztahu k procesu dramatické výchovy (SGS 4/PdF /2010: 45/6103, zdroj 1610, typ 020519). Tým tvořili pedagogové Hana Cisovská, Hana Galetková, Žaneta Káňová, Jan Karaffa a studentky PdF OU v Ostravě.
} 


\section{Výzkumná metoda a postup}

Byly použity postupy kvalitativní metody konstantní komparace, tzn. analýza na základě porovnávání dokumentů, zkušeností učitelů, výstupů a KK: syntetizace - hledáni společných a rozdílných prvků (trrídění společných jevů - kategorizace) $\rightarrow$ další údaje, zpřesňováni kategorii - formulace hypotéz $\rightarrow$ další zpřesňování - společné rysy:

1. Fáze: analýza, konkretizování a rozpracování výstupů na základě kategorizace a hledání společných znaků k jednotlivým výstupům dramatické výchovy $\mathrm{z}$ osnov a odborných publikací a $\mathrm{v}$ diskusích porovnáváním až konfrontací zkušeností vyučujících s výstupy žáků.

2. Fáze: porovnávání rozpracovaných výstupů předmětu dramatická výchova se složkami klíčových kompetencí na 1 . stupni hledání a nalezení shod a rozdílů. Porovnání doplňovaly úvahy nad tím, jak k rozvíjení klíčových kompetencí může docházet, tzn., jaké výchovně-vzdělávací strategie k rozvoji používáme.

Návrh rozpracování je inspirací a možností, jak pohlížet na očekávané výstupy na konci 3. a 5. ročníku základního vzdělávání. Všechny dílčí výstupy jsou uvedeny v publikaci Cisovská, et al. (2010). Velký význam zde sehrály praktické zkušenosti autorů této publikace právě $\mathrm{v}$ diskusích při porovnávání a nalézání shod a rozdílů ve formulacích rozpracovaných výstupů, aby odpovídaly tomu, co žáci v reálné praxi mohou skutečně zvládnout na konci jednotlivých období.

\section{Porovnání rozpracovaných výstupů se složkami klíčových kompetencí}

V tabulce 1 jde o ukázku rozpracování výstupů z RVP ZV na konci 5. třídy ZŠ a jejich přiřazení k odpovídajícím složkám klíčových kompetencí, které mohou pomáhat rozvíjet.

\section{Tabulka 1}

Přiklad komparace očekávaného výstupu: propojuje somatické dovednosti a kombinuje je za účelem vyjádření vnitřních stavi̊ a emocí vlastních i určité postavy

\begin{tabular}{|c|c|}
\hline $\begin{array}{c}\text { Rozpracované výstupy pro 1. stupeň ZŠ } \\
-2 \text {. období }\end{array}$ & $\begin{array}{l}\text { Odpovídající složky klíčových } \\
\text { kompetencí (Hučínová, 2007) }\end{array}$ \\
\hline $\begin{array}{l}\text { - používá prodloužený výdech a základy dechové } \\
\text { opory, KOM1 } \\
\text { - rozezní hlas s rezonancí na přední opoře, KOMI } \\
\text { - užívá v běžné mluvě měkkého hlasového začátku, } \\
\text { KOM1 } \\
\text { - zvládá základy správné artikulace, KOMI } \\
\text { - vyslovuje zřetelně všechny vokály v příslušné } \\
\text { kvalitě i kvantitě, KOM1 } \\
\text { - přizpůsobuje mluvní projev (rytmičnost a } \\
\text { melodičnost) a pohyb vzhledem k měnícím se } \\
\text { daným okolnostem hrané situace, KOMli4, UČl } \\
\text { - uživá různých výrazových možností pohybu, } \\
\text { KOM2 } \\
\text { - propojuje rytmus, pohyb a slovo (řeč), KOMI } \\
\text { - vyjadřuje se srozumitelně pohybem i řečí jak v } \\
\text { hrané tak reálné situaci, KOMli2 } \\
\text { - využívá všech smyslů při vnímání skutečnosti s }\end{array}$ & 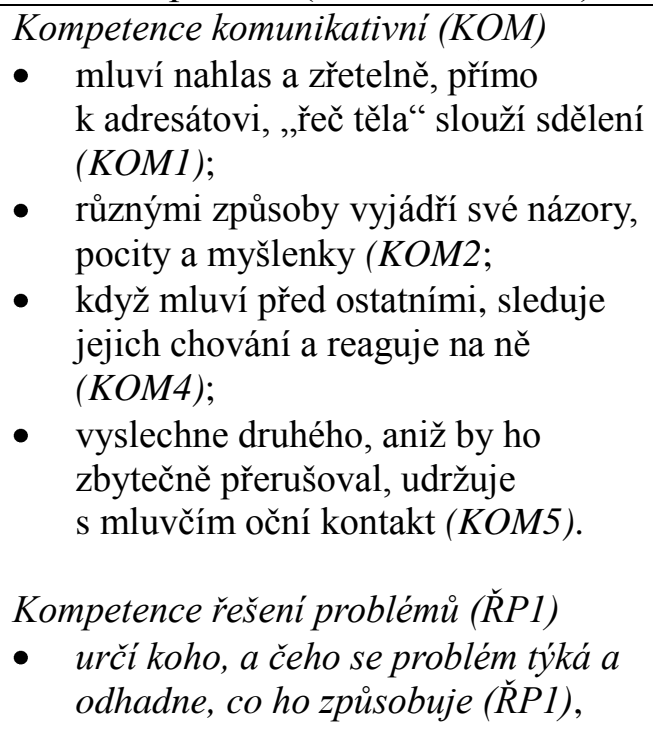 \\
\hline
\end{tabular}




\begin{tabular}{|c|c|}
\hline 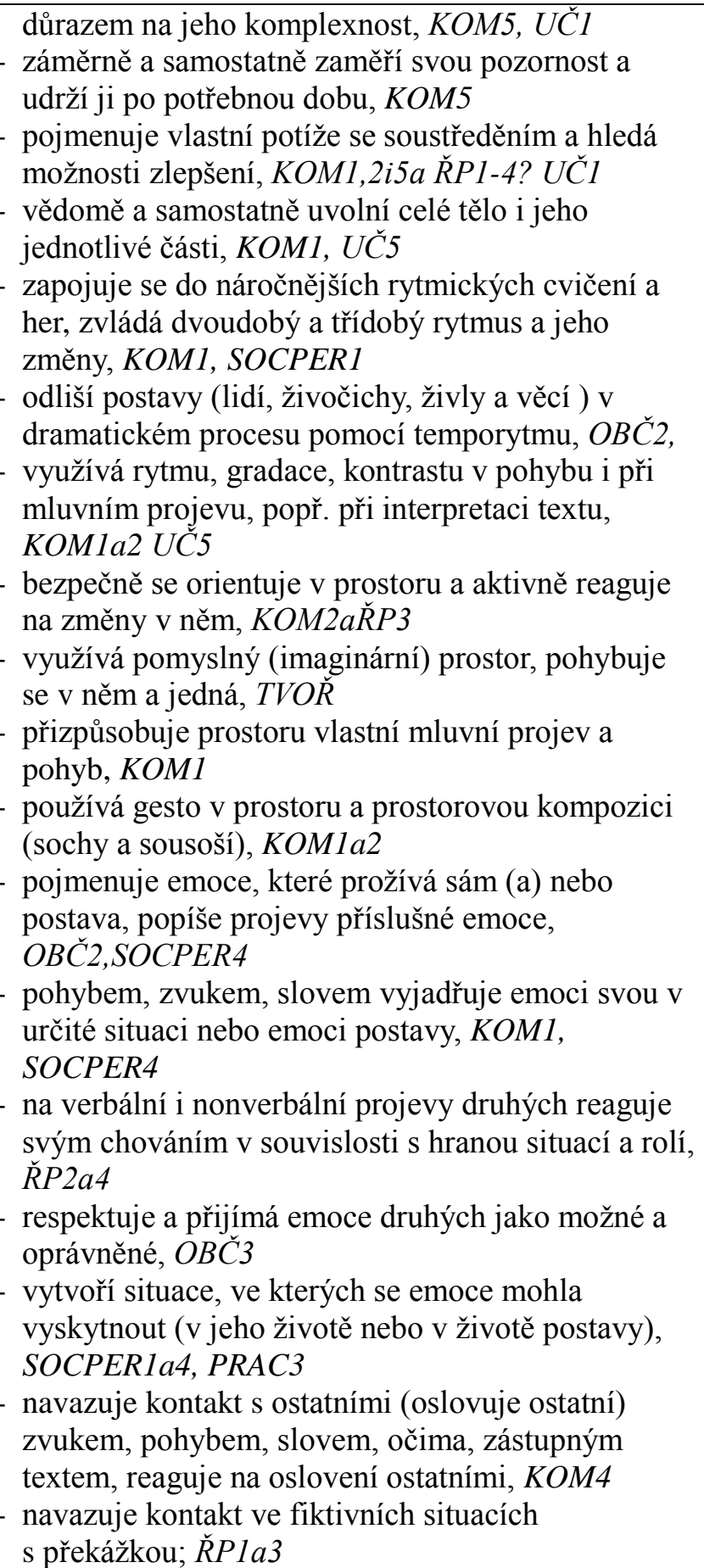 & 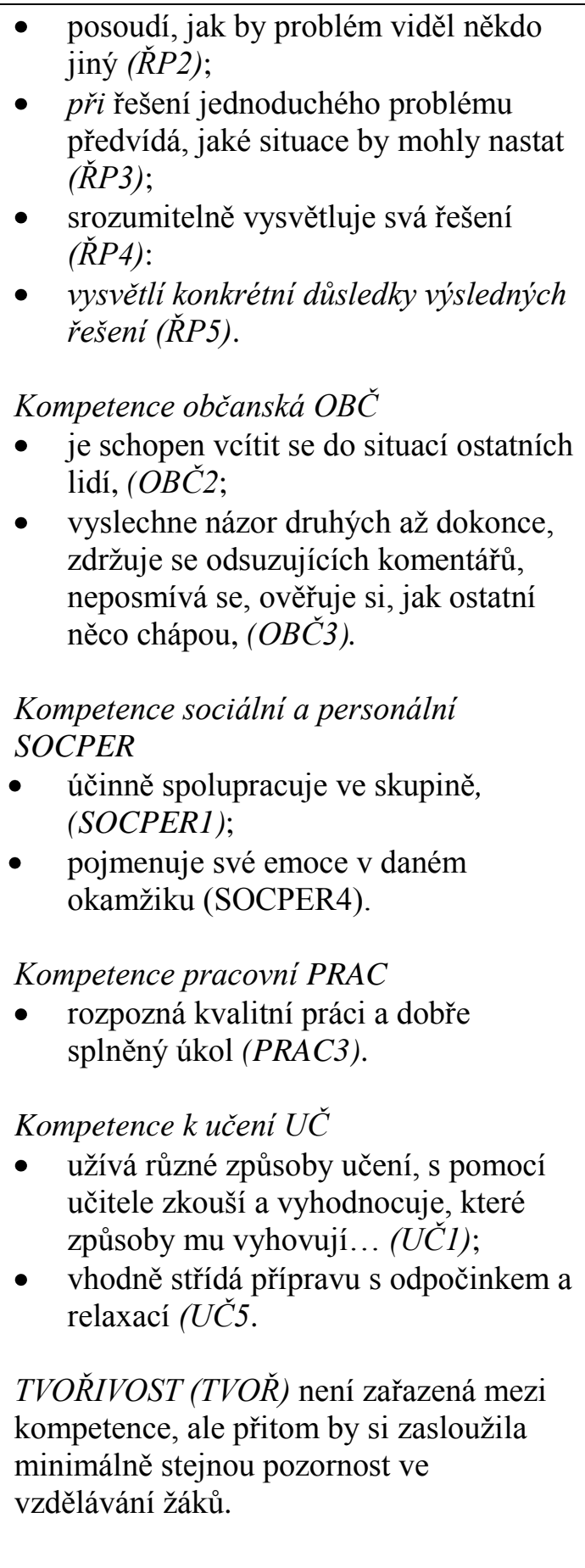 \\
\hline
\end{tabular}

Největší souvislosti má tento očekávaný výstup s kompetencí komunikativní, dále sociální a personální. Objevuje se zde také vazba s kompetencí k učení, která by mohla mít ještě větší četnost, ale záleží na konkrétním naplňování těchto rozpracovaných výstupů. Určitě je možné najít souvislosti i s jinými kompetencemi, ale u uvedených jsou vazby nejvýraznější. Součástí analýzy byl také popis vzdělávacích strategií, které rozvoji KK mohou výrazně přispívat. Je vidět, že některé rozpracované výstupy mohou být také inspirací pro samotný obsah pojetí klíčových kompetencí. Je však potřeba nějakými dalšími způsoby ověřovat, zda tomu tak může být a zda reálně v praxi k takovému vlivu skutečně dochází. Rozpracované výstupy mohou být velmi užitečné, jak pro běžnou praxi ve škole, tak i pro hodnocení, evaluaci nebo výzkum, protože umožňuje zaostřit na konkrétní ukazatele hodnot, k nimž učitelé se svými žáky mohou směřovat. 


\section{Závěry}

Dramatická výchova může přispět k rozvoji všech klíčových kompetencí v různé míře a různým způsobem, at' už je zařazena jako samostatný předmět nebo je integrován její obsah $\mathrm{s}$ obsahy jiných předmětů či vzdělávacích oblastí. Největší pravděpodobnost je však při samotném naplňování jejích výstupů, což je hypotéza k dalšímu ověřování. Všechny rozpracované výstupy velmi úzce souvisí s některou ze složek klíčových kompetencí a dokonce je mohou i vhodně doplňovat. Proto se mohou stát také východiskem pro formulování kritérií a jejich vlastností - pro rozmanité způsoby jejich hodnocení, evaluace, nebo výzkum a vytváření jejich konkrétních vlastností k zaznamenávání kvality dosažených výsledků. Na základě provedených analýz se ukazuje potřeba dalšího pokračování v řešení tohoto problému a pravděpodobně bude vhodný právě smíšený design výzkumu.

\section{Literatura}

Baldwin, P. (2008). Drama in schools. Some basic questions answered. Drama magazine, Winter. Cisovská, H. et al. (2010). Rozvoj klíčových kompetencí dramatickou výchovou a jejich evaluace. Ostrava: PdF Ostravské univerzity v Ostravě.

Delhaxhe, A., Baïdak, N., \& Horvath, A. at al. (2009). Arts and cultural education at school in Europe. Brussels: Eurydice.

Hučínová, L. et al. (2007). Kličcové kompetence v základním vzdělávání. Praha: VÚP v Praze.

Turner, H. et al. (2004). Children engaging with drama. An evaluation of the National Theatre's drama work in primary schools 2002-2004. London: Social Science Research Unit, Institute of Education University of London. Dostupné z http://eprints.ioe.ac.uk/2995/1/Turner2004Childrenengaging.pdf.

\section{Kontakt}

Mgr. Jan Karaffa, Ph.D.

Ostravská univerzita

Pedagogická fakulta, Katedra pedagogiky primárního a alternativního vzdělávání Mlýnská 5, 70100 Ostrava 1

e-mail: jan.karaffa@osu.cz

\section{Bibliografické údaje}

Karaffa, J. (2011). Analýza výstupů dramatické výchovy a klíčových kompetencí. In T. Janík, P. Knecht, \& S. Šebestová (Eds.), Smišený design v pedagogickém výzkumu: Sborník přispěvkü z 19. výroční konference České asociace pedagogického výzkumu (s. 344-348). Brno: Masarykova univerzita.

ISBN 978-80-210-5774-6.

Dostupné z: http://www.ped.muni.cz/capv2011/sbornikprispevku/karaffa.pdf

doi: 10.5817/PdF.P210-CAPV-2012-23 